\title{
PEMBUATAN COCOPEAT SEBAGAI UPAYA PENINGKATAN NILAI TAMBAH SABUT KELAPA
}

\author{
Edi Efrita $^{1 *}$, Jon Yawahar ${ }^{2)}$, Anton Feriady ${ }^{3)}$ \\ ${ }^{1)}$ Program Studi Agribisnis, Fakultas Pertanian dan Peternakan Universitas Muhammadiyah Bengkulu \\ ${ }^{2}$ Program Studi Agroteknologi, Fakultas Pertanian dan Peternakan Universitas Muhammadiyah Bengkulu \\ ${ }^{3)}$ Program Studi Agribisnis, Fakultas Pertanian dan Peternakan Universitas Muhammadiyah Bengkulu \\ *Corresponding author: yusmaniarti@umb.ac.id
}

Cocopeat dapat dimanfaatkan di sektor pertanian sebagai kompos atau media tanam untuk tanaman hortikultura seperti sayur, bunga atau buah-buahan dalam pot atau sebagai media tanam hidroponik sebagai pengganti media tanah. Dengan melihat sumber bahan baku yang melimpah dan belum termanfaatkan secara optimal tersebut, hal inilah yang melatarbelakangi diadakannya pelatihan dan sosialisasi pada Kelompok Wanita Tani "Rafflesia" di Desa Kungkai Baru Kecamatan Air Periukan Kabupaten Seluma. Pelatihan dan sosialisasi ini dilakukan dengan metode ceramah dan praktek langsung, sehingga peserta dapat menerima dan memahami tentang materi yang disampaikan oleh tim pengabdian kepada masyrakat. Kegiatan yang telah dilakukan ada beberapa manfaat yang diperoleh para peserta yaitu, peserta yang belum tahu mengenai pemanfaatan sabut kelapa menjadi nilai tambah yang dapat meningkatkan pendapatan dan mengetahui mengenai tekhnologi atau alat sederhana pemisah serat sabut kelapa yang praktis, ekonomis serta menguntungkan

\section{Kata Kunci : Pelatihan, Cocopeat, Dekortasi}

\section{PENDAHULUAN}

\section{Analisis Situasi Mitra}

Kungkai Baru adalah desa yang berada di Kecamatan Air Periukan, Kabupaten Seluma, Provinsi Bengkulu. Mayoritas penduduk desa ini adalah transmigran asal Bali, sehingga budaya Bali dapat disaksikan dengan mudah di desa ini. Jumlah penduduk berkisar 1.890 jiwa yang terbagi dalam 5 (lima) wilayah dusun. Komoditas perkebunan unggulan di desa ini adalah kelapa dan kelapa sawit. Akan tetapi dengan perkembangan perkebunan kelapa sekarang ini terdesak oleh perkebunan kelapa sawit, kelebihan tanaman kelapa adalah masih dapat tumbuh dan berbuah pada dataran tinggi.

Tanaman kelapa merupakan tanaman multi manfaat, mulai dari akar, batang, dan daunnya dapat dimanfaatkan. Akar tanaman kelapa bisa dijadikan obat, bonggol atau pangkal batang kelapa bisa dijadikan beduk atau dol yang merupakan salah satu alat musik perkusi tradisional daerah Bengkulu. Batangnya bisa dijadi kayu atau jembatan, daunnya bisa dijadikan ketupat dan lidi sapu. Buahnya yang muda merupakan minuman alami yang segar dan banyak dijual di tempat wisata, dan buah yang tua merupakan bahan baku minyak goreng, santan, dan air buahnya bisa dijadikan nata de coco, tempurung buahnya bisa dijadikan arang dan kerajinan tangan lainnya, dan dari sabutnya bisa dijadikan sapu atau keset.

Produksi kelapa di Provinsi Bengkulu pada tahun 2018 ada sebanyak 10,072 ton (BPS Provinsi Bengkulu, 2019). Dengan demikian potensi sabut kelapa mencapai 6.500 ton per tahun. Sabut kelapa sudah lama dimanfaatkan masyarakat untuk kerajinan tangan seperti keset, tali, sikat, sapu dan alat rumah tangga lainnya. Akan tetapi produk dari sabut tersebut sudah kurang diminati 


\section{OTurnall=m}

mayarakat karena ada produk sejenis yang terbuat dari plastik yang lebih tahan dan ekonomis. Oleh karena itu banyak sekali sabut yang tidak dimanfaatkan, yang hanya dibuang atau hanya dibakar. Oleh karena itu perlu diupayakan peningkatan nilai tambah sabut menjadi produk yang lebih menguntungkan. Hal ini sesuai dengan pendapat Simarmata dkk., 2019 bahwa limbah pertanian yang kurang produkstif harus dapat dimanfaatkan menjadi produk yang lebih prosfektif dan menguntungkan.

Salah satu produk sabut kelapa yang sekarang ini prospektif dan menguntungkan untuk diusahakan adalah cocopeat. Cocopeat berasal dari kata coconut: kelapa dan peat: gambut atau sabut. Cocopeat sering pula disebut coco fiber (serat sabut) atau coco coir (serbuk sabut). Cocopeat dapat dimanfaatkan di sektor pertanian sebagai kompos atau media tanam untuk tanaman hortikultura seperti sayur, bunga atau buah-buahan dalam pot atau sebagai media tanam hidroponik sebagai pengganti media tanah. Di bidang industri, cocopeat dapat dimanfaatkan sebagai absorben (Wiryanta, 2007., Dianawati, 2014. dan Pratiwi dkk., 2017). Harga cocopeat berkisar Rp. 2.000 sampai dengan 4.000/kg tergantung kualitasnya.

Untuk membuat cocopeat adalah dengan mendekortasikan atau memisahkan sabut menjadi serat dan cocopeat. Untuk itu diperlukan mesin decorticating, akan tetapi harga mesin tersebut cukup mahal. Untuk itu diperlukan metode dekortasi yang lebih murah.

\section{Permasalahan Mitra}

Sabut kelapa sudah lama dimanfaatkan masyarakat untuk kerajinan tangan seperti keset, tali, sikat, sapu dan alat rumah tangga lainnya. Akan tetapi produk dari sabut tersebut sudah kurang diminati mayarakat karena ada produk sejenis yang terbuat dari plastik yang lebih tahan dan ekonomis. Oleh karena itu banyak sekali sabut yang tidak dimanfaatkan, yang hanya dibuang atau hanya dibakar. Oleh karena itu perlu diupayakan peningkatan nilai tambah sabut menjadi produk yang lebih menguntunkan. Hal ini sesuai dengan pendapat Simarmata dkk., 2019 bahwa limbah pertanian yang kurang produkstif harus dapat dimanfaatkan menjadi produk yang lebih prosfektif dan menguntungkan.

Untuk membuat cocopeat adalah dengan mendekortasikan atau memisahkan sabut menjadi serat dan cocopeat. Untuk itu diperlukan mesin decorticating, akan tetapi harga mesin tersebut cukup mahal. Untuk itu diperlukan metode dekortasi yang lebih murah

\section{Perumusan Masalah}

Berdasarkan permasalahan mitra seperti yang telah diuraikan di atas, maka dalam pelaksanaan pengabdian ini perumusan masalah akan dikerucutkan pada Bagaimana Meningkatkan Keterampilan dan Pengetahuan Pembuatan Cocopeat Sebagai Upaya Peningkatan Nilai Tambah Sabut Kelapa di Desa Kungkai Baru Kabupaten Seluma?

Rumusan masalah tersebut adalah hasil analisa situasi yang terjadi pada mitra yang dilakukan sebelum pelaksanaan kegiatan PKM ini. Pelatihan peningkatan keterampilan dan pengetahuan dalam peningkatan nilai tambah sabut menjadi produk yang lebih menguntungkan.

Untuk membuat cocopeat adalah dengan mendekortasikan atau memisahkan sabut menjadi serat dan cocopeat. Untuk itu diperlukan mesin decorticating, akan tetapi harga mesin tersebut cukup mahal. Untuk itu diperlukan metode dekortasi yang lebih murah, praktis, ekonomis dan hasilnya sangat menguntungkan. Teknologi ini 


\section{Ourralem}

sangat membantu dan mudah dibuat untuk memisahkan sabut menjadi serat dan cocopeat.

Justifikasi permasalahan bersama dengan mitra dalam mengatasi permasalahan yang dihadapi mitra adalah:

1. Bagaimana kelompok wanita tani di Desa Kungkai Baru Kecamatan Air Periukan Kabupaten Seluma memiliki pengetahuan dan keterampilan dalam peningkatan nilai tambah sabut menjadi produk yang lebih menguntungkan.

2. Bagaimana kelompok wanita tani di Desa Kungkai Baru Kecamatan Air Periukan Kabupaten Seluma memiliki pengetahuan dan keterampilan yang diperlukan untuk menggantikan mesin decorticating, dengan teknologi murah,praktis dan ekonomis serta lebih efisien.

\section{PELAKSANAAN DAN METODE KEGIATAN}

\subsection{Tempat dan Waktu Pelaksanaan}

Kegiatan PKM ini adalah meningkatkan keterampilan dan pemahaman kepada kelompok wanita tani Rafflesia di Desa Kungkai Baru Kabupaten Seluma dalam memanfaatkan sabut kelapa menjadi nilai tambah yang lebih menguntungkan. Kegiatan ini merupakan solusi dalam mengatasi sabut kelapa yang sudah lama dimanfaatkan masyarakat untuk kerajinan tangan seperti keset, tali, sikat, sapu dan alat rumah tangga lainnya. Akan tetapi produk dari sabut tersebut sudah kurang diminati mayarakat karena ada produk sejenis yang terbuat dari plastik yang lebih tahan dan ekonomis. Oleh karena itu banyak sekali sabut yang tidak dimanfaatkan, yang hanya dibuang atau hanya dibakar. Oleh karena itu perlu diupayakan peningkatan nilai tambah sabut menjadi produk yang lebih menguntunkan. Hal ini sesuai dengan pendapat Simarmata dkk., 2019 bahwa limbah pertanian yang kurang produkstif harus dapat dimanfaatkan menjadi produk yang lebih prosfektif dan menguntungkan.

Kegiatan ini diadakan selama 4 hari pada tanggal 18, 19, 20 dan 21 Desember 2019.

1. Khalayak Sasaran

Khalayak sasaran dalam kegiatan ini adalah Kelompok Wanita Tani "Rafflesia" Desa Kungkai Baru Kecamatan Air Periukan Kabupaten Seluma

2. Persiapan dan Pembekalan

a) Mekanisme pelaksanaan kegiatan PKM meliputi tahap berikut :

i. Perekrutan mahasiswa untuk membantu proses PKM

ii. Konsultasi dengan Koordinator Penyuluh BPP Sukaraja tempat diadakan PKM

iii. Pembekalan kepada mahasiswa

iv. Penyiapan Alat dan Bahan untuk PKM

b) Materi persiapan dan pembekalan kepada mahasiswa yang terlibat dalam PKMS :

i. Sesi pembekalan (Coaching)

a. Pembagian tugas kepada mahasiswa yang terlibat dalam kegiatan PKM.

b. Panduan dan pelaksanaan program PKM

c. Sambutan dari Koordinator Penyuluh BPP Sukaraja

ii. Sesi pembekalan / Simulasi

a. Persiapan materi yang akan dibahas dalam diskusi

b. Mekanisme pelaksanaan Pelatihan seperti tanya jawab dengan peserta pelatihan pembuatan cocopeat

iii. Pelaksanaan tahapan kegiatan PKM 2019

a. Pengumpulan data infomasi KWT "Rafflesia"

b. Diskusi mengenai pembuatan cocopeat sebagai nilai tambah. 


\section{Ourmalis}

c. Praktek pembuatan cocopeat sebagai nilai tambah.

d. Pelatihan pembuatan mesin pemisah sabut kelapa.

3. Pelaksanaan

Pelaksanaan PKM ini dilakukan dengan cara memanfaatkan bahan baku sabut kelapa yang melimpah dan sudah lama dimanfaatkan masyarakat setempat untuk kerajinan tangan seperti keset, tali, sikat, sapu dan alat rumah tangga lainnya. Akan tetapi produk dari sabut tersebut sudah kurang diminati mayarakat setempat karena ada produk sejenis yang terbuat dari plastik yang lebih tahan dan ekonomis. Oleh karena itu banyak sekali sabut yang tidak dimanfaatkan, yang hanya dibuang atau hanya dibakar. Oleh karena itu perlu diupayakan peningkatan nilai tambah sabut menjadi produk yang lebih menguntungkan.

Setelah dilakukan Forum Grup Discussion dilanjutkan dengan forum pelatihan pembuatan sabut kelapa menjadi nilai tambah dan pengenalan mesin pemisah serat kelapa yang murah dan efisien, sehingga dapat menggantikan harga mesin yang mahal.

Adapun tahapan pelaksanaan PKM berupa sosialisasi dilajutkan dengan pelatihan serta Forum Grup Discussion (FGD) dan dibagi 4 tahapan, yaitu : 1) pengumpulan data dan informasi tentang keadaan Desa Kungkai Baru Kabupaten Seluma 2) pelatihan pemanfaatan sabut kelapa menjadi nilai tambah 3) pelatihan pembuatan mesin pemisah serat sabut kelapa menjadi cocopeat 4) Pembuatan bahan materi menggunakan Ms. Powerpoint.

Pelaksanaan kegiatan PKM ini dilakukan kisaran $120-180$ menit, dengan frekuensi dilakukan selama 3 (tiga) hari. Dengan maksud Kelompok Wanita Tani "Rafflesia" mendapatkan materi mengenai pengetahuan dan pemahaman yang diberikan kepada KWT tersebut benar - benar menjadi capaian yang dapat berguna dan langsung dipraktekan di daerah tersebut

\section{HASIL DAN PEMBAHASAN}

\subsection{Hasil}

Tim pengabdian memberikan solusi dengan pelatihan dan praktek secara langsung dengan harapan dapat memacu rasa Kelompok Wanita Tani "Rafflesia" melihat bahan baku sabut kelapa sudah kurang termanfaatkan, yang hanya dibuang atau hanya dibakar. Oleh karena itu perlu diupayakan peningkatan nilai tambah sabut menjadi produk yang lebih menguntungkan.

Kegiatan pengabdian kepada masyarakat yang dilakukan ini di Desa Kungkai Baru Kecamatan Air Periukan Kabupaten Seluma memberikan pengetahuan kepada para peserta dalam hal ini KWT 'Rafflesia" mengenai peningkatan nilai tambah sabut menjadi produk yang lebih menguntungkan, Dalam proses sosialisasi yang diberikan kepada peserta, pemateri memberikan materi tentang pembuatan cocopeat sebagai upaya peningkatan nilai tambah sabut kelapa selanjutnya dalam pelatihan ini peserta diberikan kesempatan untuk mempraktekannya langsung atau mengikuti arahan yang disampaikan oleh pemateri. Pemateri memberikan materi dan bimbingan kepada peserta dan dibantu beberapa mahasiswa yang ikut terlibat dalam pelatihan ini. 


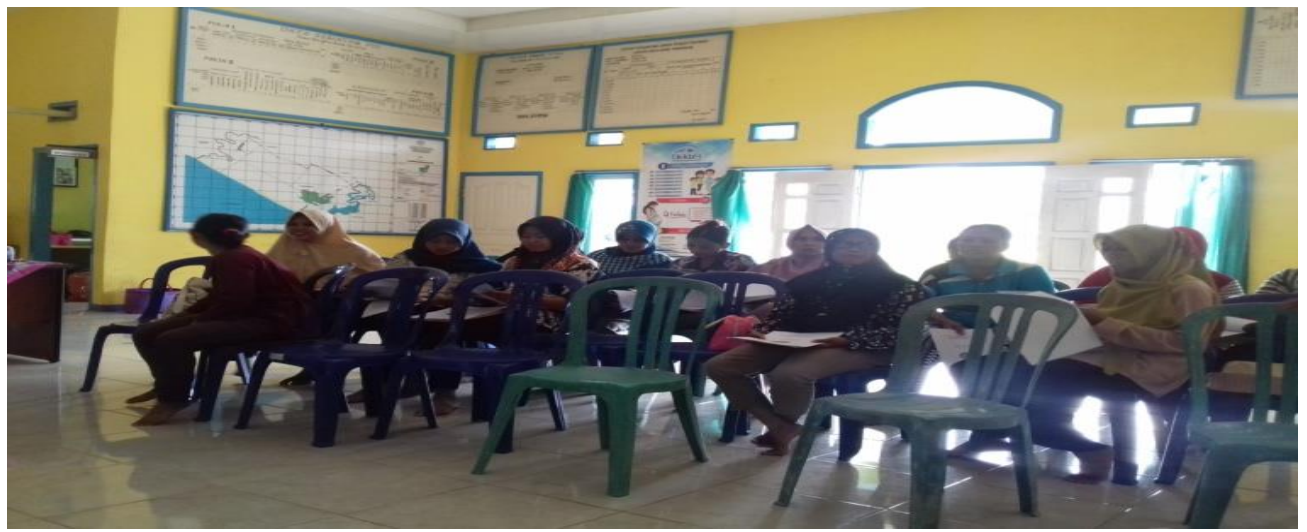

Gambar 4.1. Peserta Pelatihan KWT "Rafflesia"

Pengabdian ini dilaksanakan dalam 3 (tiga) hari dengan durasi pelatihan adalah 4 (empat) jam setiap harinya, terdiri dari: pada hari pertama tim pengabdian kepada masyarakat melakukan penyampaian materi dimulai dari acara pembukaan yang di buka oleh Koordinator Penyuluh BPP Sukaraja Kabupaten Seluma. Selanjutnya sambutan dari Ketua KWT "Rafflesia" dan Ketua Tim Pengabdian atas dibukanya proses pengabdian kepada masyarakat yang ditunjuk oleh pihak kampus yakni Dekan Fakultas Pertanian dan Peternakan Universitas Muhammadiyah Bengkulu. Pada hari pertama ini pemateri tim PKM memberikan penyampaian tentang cocopeat sebagai upaya peningkatan nilai tambah sabut kelapa. Peserta dihari pertama ini mendapatkan pengetahuan cocopeat yang bisa menetralkan kadar $\mathrm{pH}$ dan menyimpan unsur hara yang diberikan olah kita. Media ini sangat bagus sekali terutama yang memiliki hidroponik atau sebagai tanaman rumahan.

Pada hari kedua peserta diberikan pengenalan mengenai teknologi pemisah serat sabut kelapa dengan menggunakan alat sederhana, praktis dan ekonomis, yaitu alat parut atau parutan manual, tentu dengan teknologi sederhana mampu mampu menghasilkan serbuk kelapa yang diinginkan sesuai kebutuhan. Dalam materi ini peserta dikenalkan dengan alat atau teknologi sederhana tadi yang mampu memisahkan serat kelapa dan juga bagaimana cara penggunaan alat tersebut agar aman dan tidak mempunyai resiko pada saat digunakan.

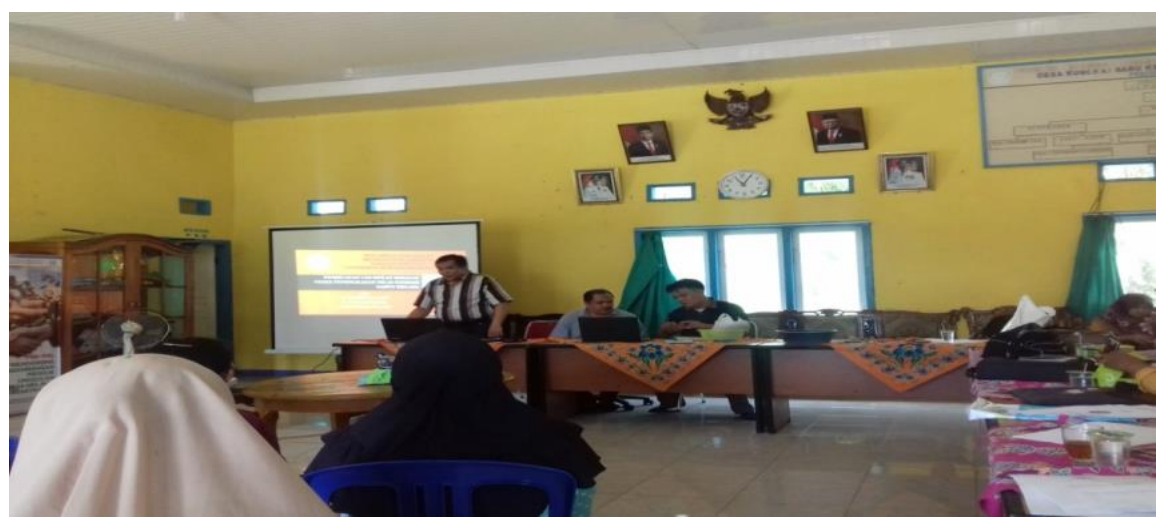

Gambar 4.2. Penyampaian Materi dari Tim Pengabdian 
Kegiatan PKM ini dilaksanakan dalam waktu 60 menit dalam menyampaikan materinya, selanjutnya peserta diberikan latihan dan praktek sesuai dengan materi yang telah disampaikan oleh pemateri dari tim pengabdian yang dibantu oleh mahasiswa yang ikut terlibat dalam pengabdian masyarakat ini.

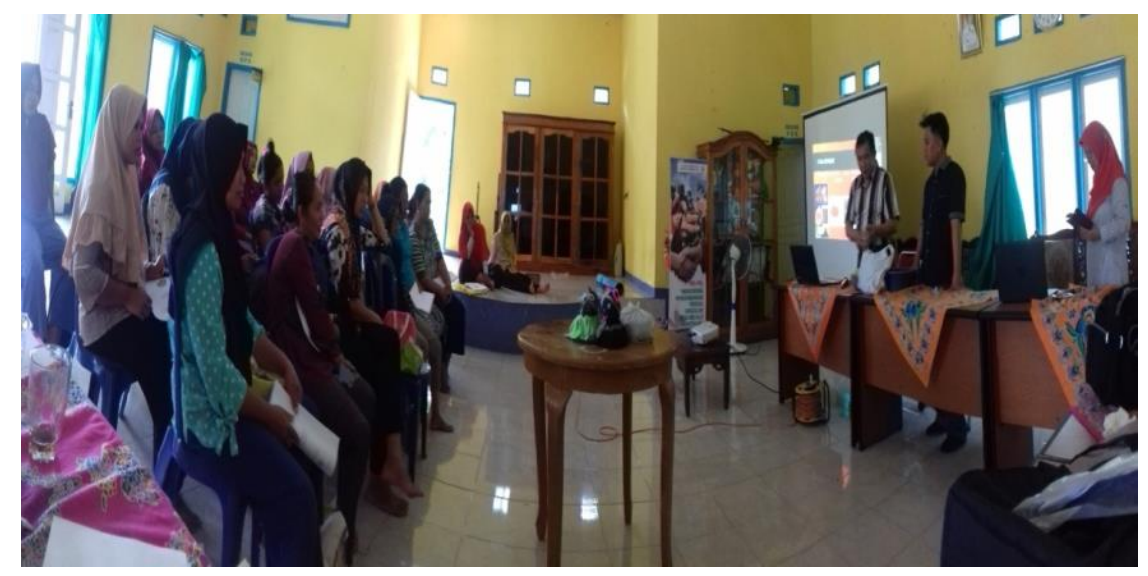

Gambar 4.3. Diskusi antara Peserta dengan Tim Pengabdian

Evaluasi dari kegiatan pengabdian ini dengan melihat kemampuan para peserta pada saat praktek langsung setelah penyampaian materi berakhir. Dilihat dari respon peserta sangat antusias mengenai pelatihan ini dan peserta mampu memahami materi yang telah disampaikan tim pengabdian masyarakat secara keseluruhan dan sangat membantu dalam memanfaatkan sumber bahan baku yang melimpah di daerah pengabdian masyarakat.

\subsection{Pembahasan}

Tanaman kelapa merupakan tanaman multi manfaat, mulai dari akar, batang, dan daunnya dapat dimanfaatkan. Akar tanaman kelapa bisa dijadikan obat, bonggol atau pangkal batang kelapa bisa dijadikan beduk atau dol yang merupakan salah satu alat musik perkusi tradisional daerah Bengkulu. Batangnya bisa dijadi kayu atau jembatan, daunnya bisa dijadikan ketupat dan lidi sapu. Buahnya yang muda merupakan minuman alami yang segar dan banyak dijual di tempat wisata, dan buah yang tua merupakan bahan baku minyak goreng, santan, dan air buahnya bisa dijadikan nata de coco, tempurung buahnya bisa dijadikan arang dan kerajinan tangan lainnya, dan dari sabutnya bisa dijadikan sapu atau keset.

\subsubsection{Sabut Kelapa dan Manfaatnya.}

Sabut kelapa adalah kulit buah kelapa, yang merupakan limbah setelah dipisahkan dari tempurung, daging buah, dan airnya. Sabut kelapa terdiri dari serat dan gabus sebagai penghubung antar serat.

Sabut kelapa mengandung senyawa kimia seperti selulosa, lignin, karbon, tannin, dan potasium. Pengolahan sabut kelapa menghasilkan produk-produk primer yaitu (1) Serat panjang (serat), (2) Serat halus atau serat pendek (Bristle) dan (3) Debu atau serbuk sabut. Serat panjang dapat digunakan untuk membuat tali, sikat, atau sapu, matras, keset, atau dianyam menjadi tikar atau jaring. Serat yang pendek dapat dibuat menjadi dapat diproses menjadi geotextile, dan lain-lain, sedangkan debu / serbuk sabut diproses lebih lanjut menjadi kompos, partikel papan untuk mebel, atau cocopeat. 


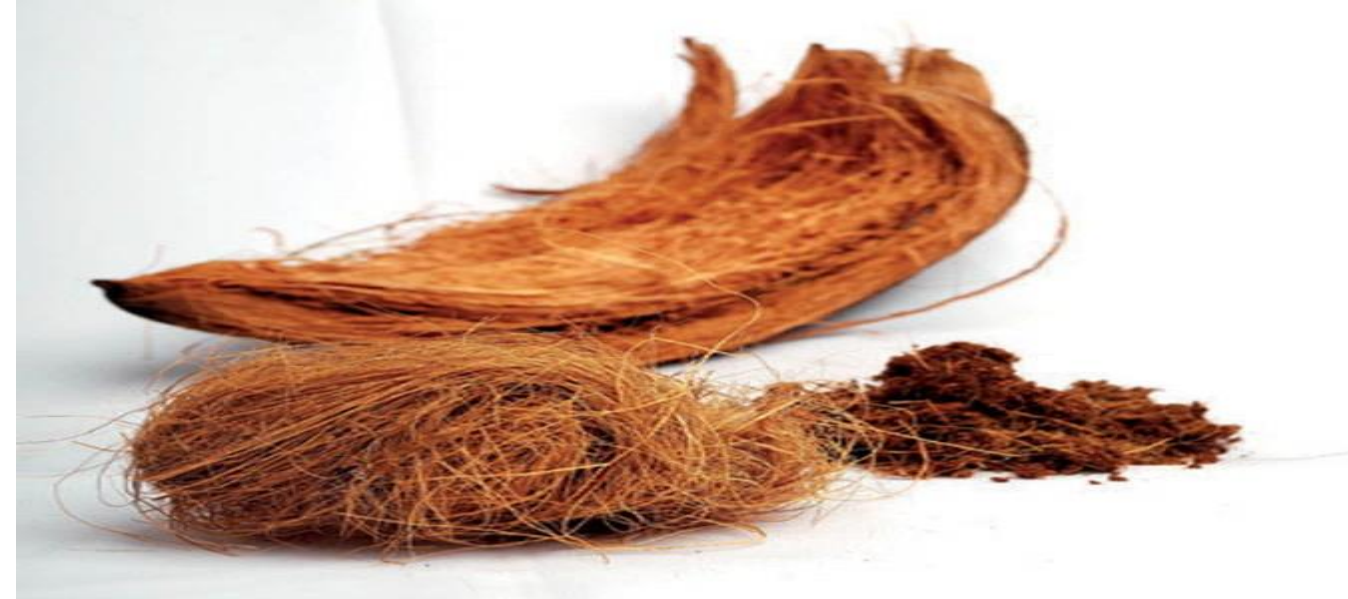

Gambar 4.4. Bahan Baku Sabut Kelapa

\subsubsection{Cocopeat dan Manfaatnya.}

Cocopeat merupakan sabut atau serat serabut kelapa yang sudah dihancurkan sehingga menjadi serbuk halus. Cocopeat ini berwarna cokelat dapat digunakan sebagai media semai, stek tanaman, juga sebagai pupuk organik, dan media tanam untuk hidroponik.Pada bidang industri cocopeat digunakan sebagai absorben.

Kelebihan cocopeat sebagai media tanam adalah:

1. Cocopeat adalah bahan yang ramah lingkungan.

2. Coco peat mempunyai daya serap air yang tinggi. Satu kg cocopeat dapat menyerap air sampai 16 liter. Karena kemampuannya dalam menyerap cairan, cocopeat dapat meningkatkan porositas tanah. Efek positifnya, tanah akan menahan lebih banyak udara dan air sehingga serta drainase pada wadah/lahan terjaga. Karena porositas/tingkat kegemburan tanah yang tinggi, pembentukan akar tanaman akan mudah dan tanaman akan lebih sehat dan subur. Tanaman sehat berarti ada lebih banyak buah di dalamnya. Sangat cocok untuk sayuran berdaun seperti sawi, bayam dan kangkung yang dibudidayakan dalam pot.

3. cocopeat terurai dalam jangka waktu 10 tahun pemakaian. Hal ini sangat menguntungkan karena pemanfaatan cocopeat dapat berlangsung lebih lama.

4. Nilai PH Cocopeat adalah 5,8 hingga 6,5, yang merupakan kisaran sempurna bagi sebagian besar jenis tanaman untuk tumbuh.

5. Cocopeat mudah digunakan sebagai media untuk budidaya tanaman terutama untuk media hidroponik karena teksturnya menyerupai tanah.

6. Mengandung unsur kimia dan unsur hara kalium serta fosfor cukup tinggi.

Meskipun memiliki banyak manfaat, tetapi cocopeat juga memiliki kekurangannya, yaitu:

1. Karena tingkat porositas tanah yang tinggi setelah menambahkan Cocopeat, akibatnya kekuatan akar tanaman untuk menghunjam pada media tanam menjadi berkurang. Untuk ini, perlu memberikan ajir/pendukung untuk tanaman.

2. Karena kemampuannya dalam menahan air, ada kemungkinan terjadi stagnasi air (kelebihan air) di tanah, yang dapat menyebabkan kematian tanaman atau busuk akar.

3. Cocopeat mengandung garam alami. Karenanya, Sobat harus memberikan nutrisi yang sesuai dengan kadar garam yang terkandung didalamnya.

4. Kandungan nutrisi cocopeat rendah sehingga perlu ditambahkan 
komponen lain sebagai media tanam pengganti tanah.Penambahan kompos atau pupuk organik lain serta sekam akan menjadi alternatif campuran media tanam yang baik.

5. Cocopeat mengandung tanin yang dapat menjadi racun bagi tanaman dan menghambat pertumbuhan tanaman.

6. Cocopeat secara alami mengandung fungi Trichoderma sp.

7. Kandungan klor $(\mathrm{Cl})$ pada cocopeat masih tinggi sehingga bila bereaksi dengan air akan membentuk senyawa asam klorida $(\mathrm{HCl})$ yang membawa sifat asam.

\subsection{Cara Membuat Cocopeat.}

\subsubsection{Bahan}

Bahan yang digunakan adalah sabut kelapa dari kelapa yang sudah tua, kaleng susu, kayu, paku, plastik kemasan. 4.4.2. Alat.

Alat yang digunakan adalah gunting seng, baskom dan ayakan.

4.4.3. Prosedur.

Langkah pertama yang dilakukan adalah membuat alat dekortasi atau pemisah serabut dari sabut kelapa. Cara kerjanya adalah:

1. Buanglah sisi atas dan sisi bawah kaleng bekas susu.

2. Belahlah kaleng tersebut.

3. Buatlah lubang pada kaleng tersebut secara teratur dengan jarak lebih kurang $0,5 \mathrm{~cm}$ dengan menggunakan paku.

4. Setelah selesai membuat lubang di seluruh kaleng tersebut, pakukanlah kaleng tersebut pada kayu bulat.

Langkah kedua adalah mengdekortasikan sabut kelapa. Cara kerjanya adalah:

1. Ambillah sabut kelapa. Sabut kelapa tersebut haruslah kering dan berasal dari buah kelapa yang sudah tua yang tandanya adalah kulitnya sudah berwarna cokelat tua.

2. Parutlah sabut kelapa tersebut pada bagian dalamnya yang berwarna coklat kekuningan sehingga menghasilkan serbuk sabut kelapa.

3. Jemurlah serbuk yang dihasilkan sampai kadar airnya di bawah 15 persen.

4. Ayaklah dust untuk memisahkannya dari serat panjang, serat pendek, sehingga dihasilkan serbuk yang mempunyai tekstur yang sangat halus dan inilah yang akan digunakan sebagai cocopeat.

5. Setelah selesai diayak, kemaslah cocopeat yang dihasilkan.

6. Cocopeat yang dihasilkan bisa pula dipres berbentuk balok, papan, atau cakram. (Veranika dan Fauzie, 2020).

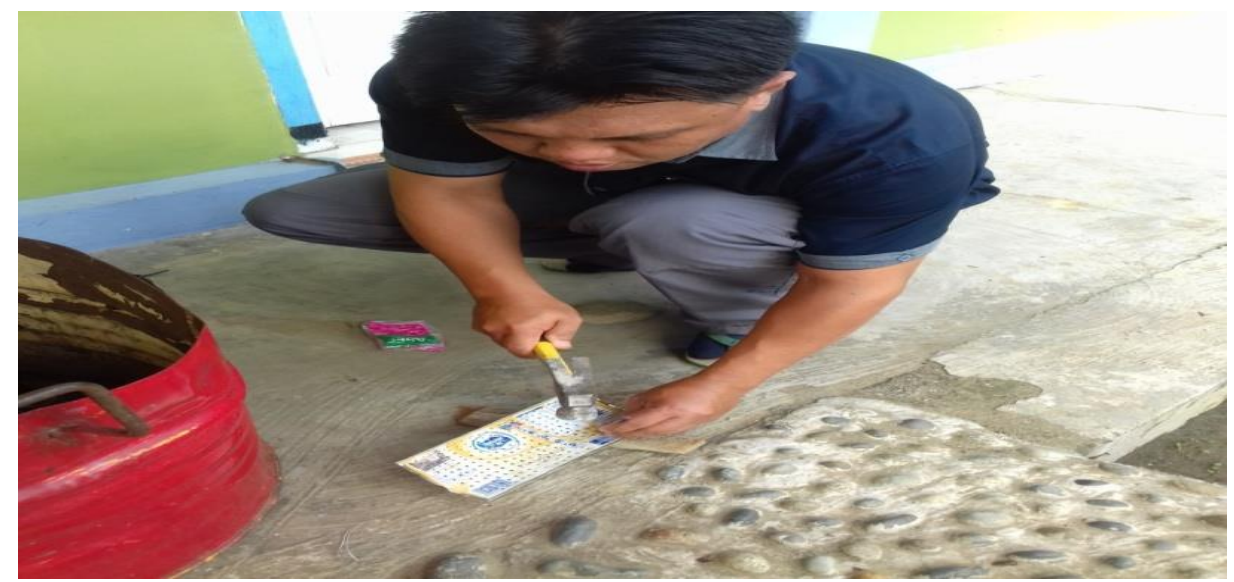

Gambar 4.5. Pembuatan Alat Pemisah Serat Kelapa 


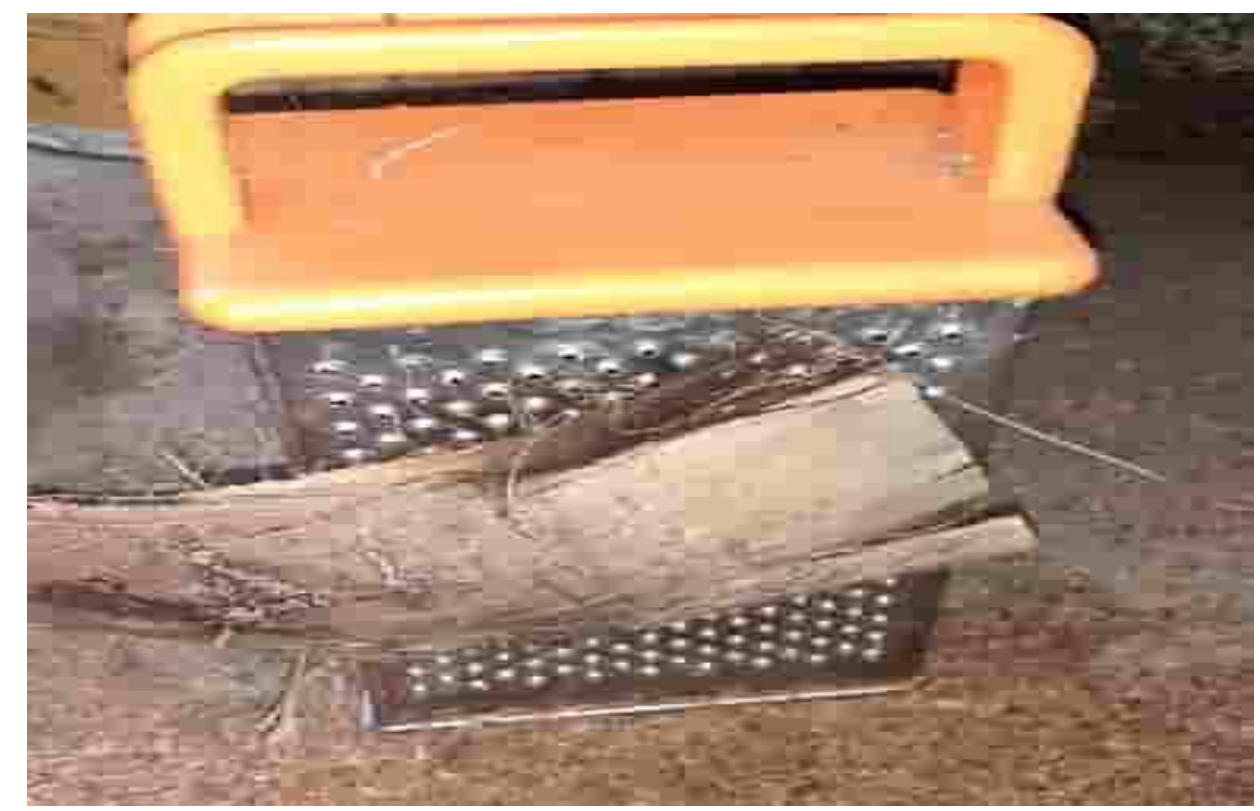

Gambar 4.6. Teknologi atau Alat Pemisah Serat Kelapa yang siap digunakan

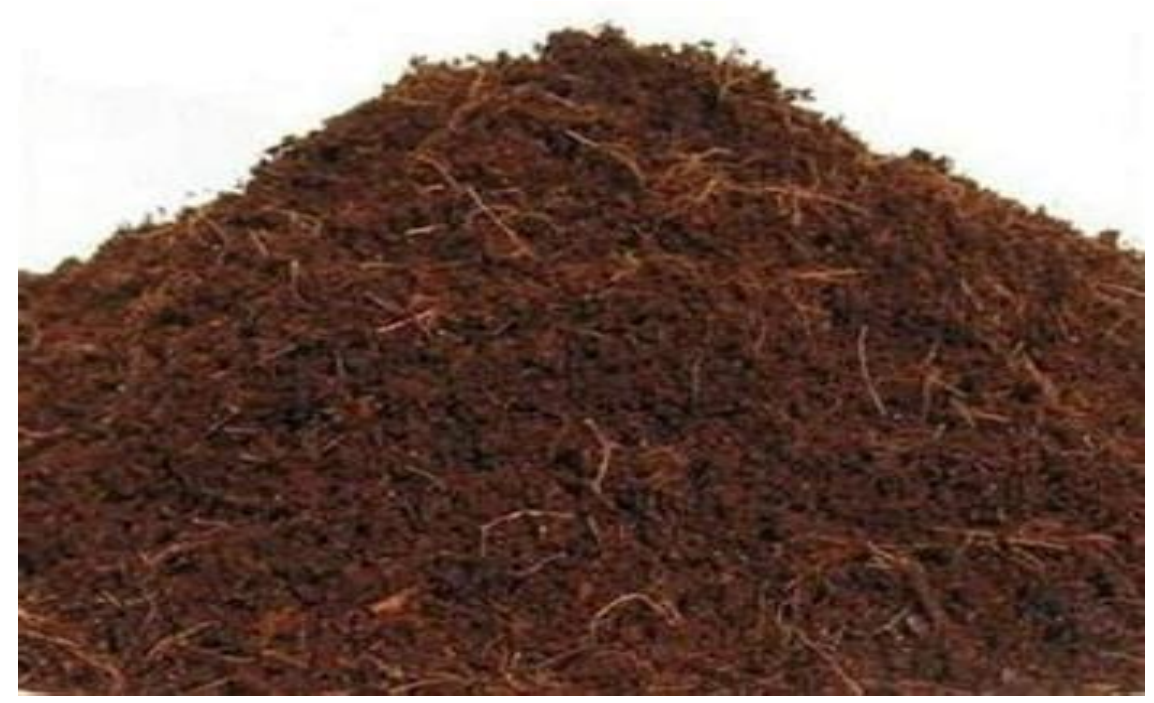

Gambar 4.7. Serat Kelapa yang sudah dipisahkan / Cocopeat Siap digunakan atau dikemas

Selanjutnya cocopeat tersebut dapat dijual ke konsumen baik berupa curah atau yang sudah dipres. Cocopeat tersebut dapat pula digunakan sendiri. Apabila cocopeat yang dihasilkan sangat kasar sebaiknya digunakan untuk membuat kompos. Apabila halus dapat digunakan sebagai media hidroponik.

Yang perlu diingat pada saat pemakaian cocopeat untuk media hidroponik adalah dengan terlebih dahulu merendam atau mencuci cocopeat. 


\section{Ourratsm}

Pencucian dilakukan untuk menghilangkan unsur-unsur seperti kalium, natrium dan klorida. Dalam proses pencucian ini, kandungan garam di dalamnya akan berkurang sehingga cocok untuk digunakan di tanah. Perendaman dan pencucian juga ditujukan untuk menghilangkan zat tanin yang dapat menjadi racun bagi tanaman. Kandungan zat tanin ditandai dengan munculnya warna merah bata saat cocopeat direndam dalam air. Apabila warna air rendaman sudah jernih, maka cocopeat sudah bisa dipastikan bebas dari tanin.

Demikianlah proses pembuatan cocopeat. Cocopeat ini bisa meningkatkan nilai tambah sabut kelapa yang prospektif dan menguntungkan. Usaha pembuatan cocopeat ini apabila ditekuni bisa pula menjadi salah satu usaha sampingan dan dapat meningkatkan pendapatan petani kelapa yang bahan baku tersebut melimpah.

\section{PENUTUP}

\section{Kesimpulan}

Kegiatan yang telah dilaksanakan Tim Pengabdian oleh Dosen Fakultas Pertanian dan Peternakan Universitas Muhammadiyah Bengkulu yang di bantu 2 orang Mahasiswa Program Studi Agribisnis Fakultas Pertanian dan Peternakan dapat disimpulkan Kelompok Wanita Tani "Rafflesia" ssebagai peserta pelatihan telah mendapatkan pelatihan "Pembuatan Cocopeat Sebagai Upaya Peningkatan Nilai Tambah Sabut Kelapa di Desa Kungkai Baru Kabupaten Seluma", selain itu juga ada beberapa manfaat yang diperoleh para peserta antara lain sebagai berikut:

1. Peserta yang belum tahu mengenai pemanfaatan sabut kelapa menjadi nilai tambah yang dapat meningkatkan pendapatan dan sangat menguntungkan

2. Peserta pelatihan telah mengetahui mengenai tekhnologi atau alat sederhana pemisah serat sabut kelapa yang praktis, ekonomis dan menguntungkan

\section{Saran}

Kelompok Wanita Tani "Rafflesia" khususnya ataupun masyarakat Desa Kungkai Baru umumnya untuk dapat memanfaatkan nilai tambah sabut kelapa yang selama ini hanya dimanfaatkan masyarakat untuk kerajinan tangan seperti keset, tali, sikat, sapu dan alat rumah tangga lainnya. Akan tetapi produk dari sabut tersebut sudah kurang diminati mayarakat karena ada produk sejenis yang terbuat dari plastik yang lebih tahan dan ekonomis. Oleh karena itu banyak sekali sabut yang tidak dimanfaatkan, yang hanya dibuang atau hanya dibakar. Oleh karena itu perlu diupayakan peningkatan nilai tambah sabut menjadi produk yang lebih menguntungkan dan tentunya dapat menambah pendapatan keluarga.

\section{DAFTAR PUSTAKA}

BPS Provinsi Bengkulu. 2019. Provinsi Bengkulu Dalam Angka. BPS Provinsi Bengkulu. Bengkulu.

Dianawati, M. (2014). Penggunaan Pupuk Kandang Dan Limbah Organik Sebagai Media Tanam Produksi Benih Kentang Use Manure And Organic Waste As Planting Media Of Seed Potatoes Production. Jurnal Pertanian Agros, 16(2), 292-300.

Pratiwi, N. E., Simanjuntak, B. H., \& Banjarnahor, D. (2017). Pengaruh campuran media tanam terhadap pertumbuhan tanaman stroberi (Fragaria vesca L.) sebagai tanaman hias taman vertikal. Agric, 29(1), 11-20.

Simarmata, T., Herdiyantoro, D., Setiawati, M.R., Suryatmana, P., Nurbaity, A., Anggraeni, D. S., 
Harlia, E., Marlina, E. T., Fitriatin, B. N., dan Hindersah. R. 2019. Pemanfaatan Limbah Pertanian. Editor. Universitas Terbuka. Tanggerang Selatan.

Wiryanta, B. T. W. (2007). Media tanam untuk tanaman hias. AgroMedia.

Rifki Fadil, M. U. H. A. M. A. D. (2019). Nilai Tambah Dan Kelayakan
Usaha Agroindustri Sabut Kelapa (Doctoral Dissertation, Universitas Siliwangi).

Veranika, R. M., \& Fauzie, M. A. (2020). Pembuatan dan Perancangan Alat Pengurai Sabut Kelapa Secara Manual. Jurnal Desiminasi Teknologi, 8(1). 